UCRL- 86890 (Revised) 1 PREPRINT

STABILITY AND DISTURBANCE

OF LARGE DC SUPERCONDUCTING MAGRETS*

S. T. Wang

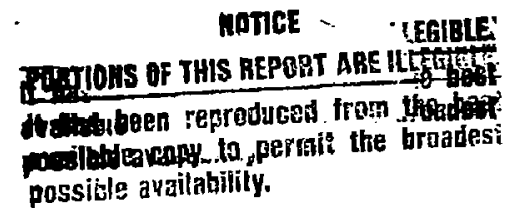

THIS IS AN IINITED PAPER FOR THE VEETINCS OF TH" SCIENTIFIC AND TECHNICAL COMISSIONS OF THE I.I.R.

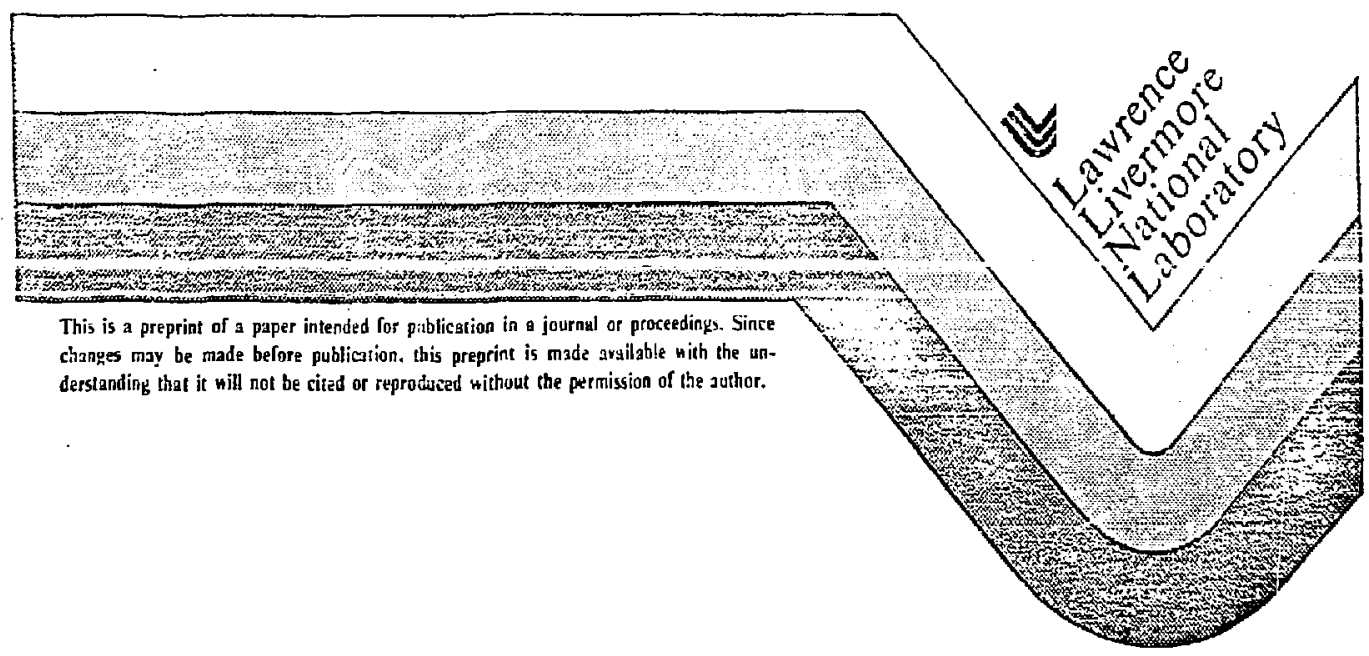


STASILITY ALD DISTERBAMEE

OF LAKGE DC SUPERCONDLCTIKG PAGHETS*

\section{T. Wisic}

University of Californic, Lasence Liverrore liational Luboratory

P. 0. 80x $5514 \mathrm{~L}-63 j$

Livemore, California 94550 (U.S.A.)

SUMHARY

This paper addzesses the stability aspects of several successidul de superconduct ing nagnets such os large bubile chataber pingnets, ond capnets for tiee Mirror Fusion Test Facility and MHD Research Facility. Specifically, it uill cover Argonne Hational Laboratory 12-Foot bubble Chamber rognets, tne 15-foot Bubble Chatrber magnets at Fcrmi Kational Laborjtory, the vTTF-B Magnet Systen af Lawrence Livermore Fational Laboratory, the V-25B Bypdss HyD hagnet, and the CFFF Supe:conducting M!H gagnet built by Argonne National Laboratory. hl] of these ragnets are cooled in paol-boiling modr. Magnet design is hriefly reviewed. Discussed in detail are the adopted stability critera, analyses of stubility and cisturbance, stability simulation, and the final resules of naguat porformance and the observed coil disturbances.

\section{THE ARCONE 12-FOOT ELBSLE CHAYOER MAGNEI /W}

A. Magnet Design Review-The 12-Foot âbble Chamber Hagnet was designed to generate a 1.6 T cenzral field in a field volume of approximately $4.5 \mathrm{n}$ diameter by 3.1 n high. The overall coil assembly consists of twa coil halves separated by 53 cn for beam access. Each coil half consists of fifreen pancakes clamped to a central stainless steel girder ring vith seven pancakes an one side and eigit on the other. The complete characteristics of the coils are given in Iable I.

The pascake to pancake spacers are insulated aluninus spacers kaving a cross section of $5.08 \mathrm{~cm} \times 1.27 \mathrm{~cm} \mathrm{thick}$.

The conduecor is a composite with six untwisted strands of witb-48: Ti retallurgically construded into an OfHC copper serip of dimensions $3.0 B \mathrm{ca} x$ $0.508 \mathrm{~cm}$. Only $4 \mathrm{~m}$ of tha ovecall cross section is superconductor. The rendinder being OFHC copper with a resistivicy racio of 200 . The actual teasured characteristics are $4000 \mathrm{~A}$ ar $2.5 \mathrm{I}$ parallel field.

The turn-to-turn insulation is glass tiber-filled teflon, 0.25 tan thick by 50.0 an wite, epoxy bonded to the conductor, alloving only edge cooling an the nerrou face of the conductor.

\section{TABLE I}

\begin{tabular}{|c|c|c|}
\hline $\begin{array}{l}\text { Yagnet characteristics of } 12-\mathrm{E} \text { oo } \\
\text { Magnet characteristics }\end{array}$ & $\begin{array}{l}\text { id } 15-\text { foot but } \\
\text { 12-foot }\end{array}$ & $\begin{array}{l}\text { chamber ragnets } \\
15-\text { foot }\end{array}$ \\
\hline Central field & $1.6 \mathrm{~T}$ & $3.0 \mathrm{~T}$ \\
\hline Peak field & $2.0 \mathrm{~T}$ & $5.15 \mathrm{~T}$ \\
\hline Operating current & $2,200 \mathrm{~A}$ & $5000 \mathrm{~A}$ \\
\hline Stored energy & $60 \mathrm{MJ}$ & $396 \mathrm{MJ}$ \\
\hline Induetance & $40 \mathrm{H}$ & $31.7 \mathrm{H}$ \\
\hline Total ampere-tums & $5.54 \times 10^{5}$ & $14.3 \times 10^{6}$ \\
\hline $\begin{array}{l}\text { Hinding i.d./o.d. } \\
\text { Separation between two coils }\end{array}$ & $\begin{array}{l}4.18 \mathrm{~m} / 5.26 \mathrm{~m} \\
54 \mathrm{~cm}\end{array}$ & $\begin{array}{l}4.27 \mathrm{r} / 5.08 \mathrm{~m} \\
99 \mathrm{~cm}\end{array}$ \\
\hline No. of ccil pancakes & 30 & 43 \\
\hline No. of turns per pancake & 84 & 65 \\
\hline Average current density & $775 \mathrm{~A} / \mathrm{c \mathbb {O } ^ { 2 }}$ & $18 B 5 \mathrm{~A} / \mathrm{Cm}^{2}$ \\
\hline Current density in conductor & $1700 \mathrm{~A} / \mathrm{cm}^{2}$ & $3700 \mathrm{~A} / \mathrm{cm}^{2}$ \\
\hline Tocal conductse weignt & $47,600 \mathrm{~kg}$ & $56,000 \mathrm{~kg}$ \\
\hline Heat transfer required & $0.1 \mathrm{~W} / \mathrm{cm}^{2}$ & $0.15-0.4 \mathrm{k} / \mathrm{e \textrm {n } ^ { 2 }}$ \\
\hline
\end{tabular}

2This work was performed under the auspices of the U.S. Departeent of Energy by Latrence Livemore Laboracory under contract No. H-74050-Eng-46. 
D. Coil Stabilizatiomprsirn Critrea and sirulakion Trests--It was decited to use enouph U:HC copper crens section to keep the hoop stress within the coppes yield stresses. This results in a rathpr large copper/supercontuctor cross sccticnal ratio and a very conservative stabilization desagn. The resistance per ca length of conductor is $1.3 \times 10^{-8}$ ohtas at $4.2 \mathrm{l}$ and 2 Tesla. Thus, ever if the total 2200-A operating current flowed through the copper only, the raxizun cenprasure rise is $0.1 \mathrm{k}$. This peak terperature is vell below the trensition terperature of the superconduccer under the operating t.-I conditions. It is therefore impossible for the superconductor to even zo norral as long as it is antrained in a liquid heliug bath.

The stability design for the conductor was checked by winding a six-parzzie coil of $60-\mathrm{cm}$ ID, 85- $\mathrm{cm}$ ob and $35-c m$ height. The total vinding lengti was $650 \mathrm{n}$ and the coil weight was $800 \mathrm{~kg}$. The intertum insu-arion and the inter-parzzike spacing are identical to that of the hubble chamber nagnet. The test coil car-ied a superconducting current of $4650 \mathrm{~A}$ while developing 2 mexinun parallel tield of 3 $T$ and a $1.4-T$ perpendicular field before the current sharing occuss. it $7200 \mathrm{~d}$, the conductor themal runatuay and the transition of nucleste-to-filis joiling occurred. In ozder to return to the superconducting state, the coil cursent was reduced to 3379 A to allow transition back to nucleate boiling.

C. Magnet Perfonaanc Tests and Observed Coil Distutbences--During the first two tests, it was inpossible to maintain a horizontal sustace of separation jetween liquid end gas because the cryostat had only one gas-eriaust line. Conseçueatly, the licuid level in the opposite region of the exhaus: pipe was several incies be low the top pancakes. This resulted in quenches of the two top pancakes at 1300 arperes and 1000 amperes. After installation of four equally spaced exhaust pipes, the engnet uas successfully energized to 1.84 T. During the charge and the discharge, both the unbalansec voltages between the two soil halves and the $23 / \mathrm{dt}$ pick-up coil vere monitored to measure the increase or decrease of the induc:snce. Tho types of signals vere observed as shown in fig. 1. The first type is a signal of short Juration and latge applitude. The time duration is an order of 100 as and

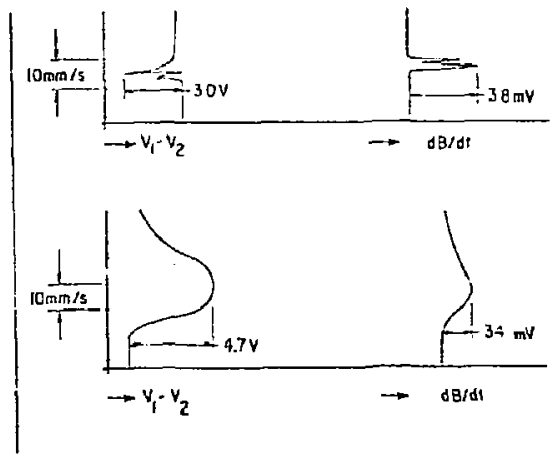

Fig. I - linbaluaced voltage and coil. sovezcat indications

the amplitude of $\left(v_{1}-v_{2}\right)$ ranges from a feu hundred nillivolts to a fer volt 5 . These signals indicate the fast but small conductor motion. The secord types are the signals of long duration. The $\mathrm{dB} / \mathrm{dt}$ signals ate, thus, of small amplitude; these signals probably represent the slow mechanical movements of the coil. 
2. THE FFRTI LABORATORY IS-FOOT BLIGLE CUAMBER YAGYET /2/

a. Coil Structure--The 15-ft Bubble Chanher :tagnet was designed, constructed, and delivered to Fer.i liational iaboratory by rirgonee Hational luboratery. The magart has designed to generate a central field of $T \mathrm{~T}$ in a field volure having a cleat hore of $3.96 \mathrm{~m}$ diatreter by about 3.42 is in igeight. There was no iron shield arourd the ragnet. The corplete characteristics of the coils are given in Toble I

The coil assembly corsists of two coil halues separated $3 y$ a gas ef $99 \mathrm{~cm}$. The pancakes, which total 43, are series-cconected, vertically stactzed, and clamped directl; to the botcors plate of the crostat.

The conductor cross section is $3.76 \mathrm{~cm}$ in height by $0.38 \mathrm{ca}$ in thichesess. In each pancoke, the coricuctor ins wound vith a 394 stainless steel strip of $0.19 \mathrm{ca}$ thic's by 3.8 co hizh. The Hicarta spacurs hetveen pancakes, f.35 the thick by 2.54 cn wide, provide 50 ; coverage on the edge surface of the pancjke coil.

for manufacturing rensons, the conductor was subdivided into four companents as shotn in $\mathrm{E}$ ig. 2. The superconducting 5 trip is $1.27 \mathrm{ca} X 0.254 \mathrm{ch}$ with an aspect tatio of $5: 1$. The copper-torstperconductor (bibT) ratio is $4: 1$. The nurber of filuents is 60 and the filament size is 0.38 and dianeter, which is small erough for sufficient heai transfer fron superconducting filarent to copper and yet large encugh for casy and reliable candacturing. These filagents are twisted at one twist pez $30 \mathrm{~cm}$. Tre backing strip of copper sets the oyeall width of the conductar at $3.76 \mathrm{~cm}$. The two smaller coppe: pieces, $1.22 \mathrm{co}$ wide bo $0.254 \mathrm{~cm}$ thisk, have transverse grooves, $0.5 \mathrm{~m}$ deep by 3.17 yice, giving a 50 \% surface for cooling. The assembly of the four corponents was done by sof t-soldering (50-50 tin-lead).

d. Co:I Srabilination-Desiga Critera and Simmlation Tests--Classieal full stabilizstion criterion was used. Both the edge-cooling and the facecool ing are utilized to provide sufficient surface area exposed to liquid helicia. For cige-cooling, the wetred area per en lengrh sonductor is $0.572 \mathrm{cs}^{2}$. The hear exchange coefficient used is $0.4 \mathrm{~W} / \mathrm{cm}^{2}$. For face cooling, the surf ace is 2.5 $\mathrm{cm} / \mathrm{cm}$ and the heat transfer coefficiene for such shallow chanels is 0.15 $\mathrm{H} / \mathrm{cr}^{2}$. Thus, the conductor exposed surface vill remove $0.6 \mathrm{H} / \mathrm{cr}$. On the other had, the resistivicy of copper including nagnetcresistence is $3 \times 10^{-8}$ ohm $-\mathrm{cm}$. Thus, the I2h power dissipation per en lergth of conductor, when it is 100 z nor=al, is $0.585 \mathrm{~N} / \mathrm{cr}$.
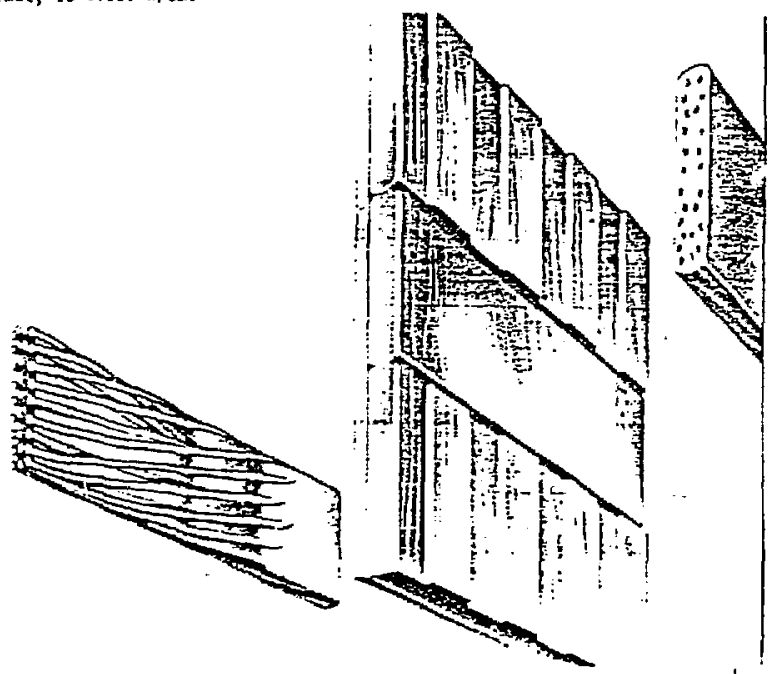

Fis. I - Cunductor consiguration for 15-FT Bubble Chinber ilagnet 
In order co tese the stability of the 15-5t Pubble Chomber Lagret conductor, a 2-Ft rodel ragnet of 8 pancaites stacking cogether was cested. A 3-ft lemeh heate: was wound with thr conductor. The nagnet was charged to 6000 it, 4500 a and $5560 \mathrm{~A}$. In each case, the conductar went nomaliy with 100 wate of heatcr porer $\{1.08$ $\mathrm{k} / \mathrm{cm}$. E:en when the heafer poxer uas raised co as high as $300 \mathrm{i} / 3.24 \% / \mathrm{cm})$, the nomal Iupion still would not propagate. Whet, the rocel ragnet us ecegoized to $7100 \mathrm{~A}$. Ho detectuble nonal zone were abserved. At this current level, the magnet develojed a $4-T$ axisl field and $2.5-T$ peak radial field.

c. Yarnet Perfomance Tests and Observed Coil Disturbances--Testing of tive bubble chambe ragnet went very well. The nagnet current was increasec in steps of 100 amper 25 each, and dumped fraçuenty ro nonicor suiten arcing. It was successfully charged to Eull design fieid ( $T$ at the center of tioe ragnet) at 500 ? A. During energization and durping, the differences in voltage bertoen the uppar coil half and the loder coil half were recorded. A conplate st.arge cycia only produced approxicately 10 small voltage spikes of a feu nillivolts ejch. In conparison, Argonne's 12-Fr Bubble Chamber magnet gave Cisturbance sienals severa: orders of magnifede in bork the nuter and voltage excursion. Ite reasen given uas that the Formi rastet used twisted superconducting filanents. Furthersose, the pancate coil structure is probably completely elastic iuring the erezization. On the other hand, the all aganet used untuisted superconducting filanents ohich contriouted to a large flux junp as well as the twisting zocce on the corcuctor resulting from the interaction of shielding current wich the magret ic field.

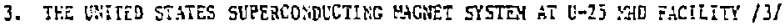

A. The Yagnet Desiga Review-In Hay 1977, the Argane National Laborator: successfully corpieted design and construction of the United States Superconducting Magnet Syster (U.S. SCMS) for use in the bypass loop of the U-25 rab farilicy in بoseou, U.S.S.R.

The geomety of the eagnet and the on-axis field intensity ate show in Fig. 3. The significant ragret chacacteristics ane listed in Table II.

The selected coil configuration is a circula: saddle shape. Each laver consists of two separate coil halves. The central poction of each coil ralf is the coil fort, which is rade of a slotted Hicarata sheet of $0.9375 \mathrm{ca}$ in thicknass.

The conductor is cryostable with an overall Cu/tubti ratio of apcozoxinately 15:1. It has a cross section of $0.2-\mathrm{ca}$ by $1,0-\mathrm{cm}$ and is a solderec assecibly of a recrangular superconducting composice strip fit into a rectangular chancel of 0.2 ca by L.O ca OrFC stabilizer. The number of filaments is 60 . The filarent diamater is $150 \mathrm{~mm}$ and the twist pitch is $15 \mathrm{~cm}$. Two grades of conductors are used; one (Grade $A$ ) with a short sample of $1100 \mathrm{~A}$ at $6.5 \mathrm{I}$ and the other (Grade $B$ ), $1100 \mathrm{~A}$ at $4.5 \mathrm{~T}$.

The turr-toturn insulation consists of three layers of Mylar tapes uith an orerall thickness approximately equai to $0.025 \mathrm{~cm}$. The ridth of the tapes is 1.025 cE. The narrow faces of the conductor will be bare. Ficty percent of the coaductor's narrow faces will be exposed to liquid heliun. Fig. 4 shows the layer-tolazer structure at both the straight coil region and the coil end region.

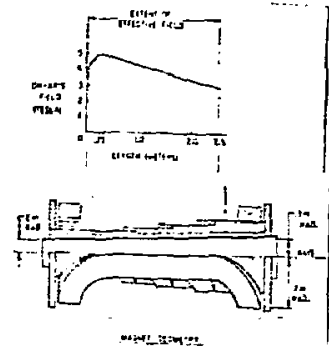

Fís. 3 - Us SCils field and coil geonetry vs. Iength

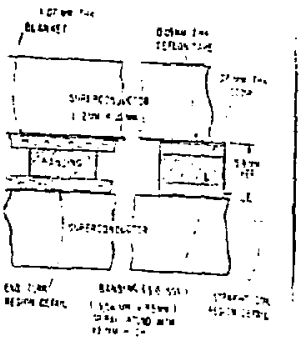

Fig. 4 - US se's layer-to-layer scruicure 


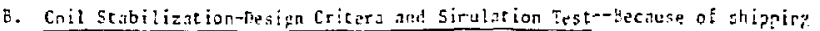
constrairis, che cail size russ be kept as stejit as fossible, and, thes, a currans density of about $5000 \mathrm{~K} / \mathrm{cm}^{7}$ was tirgeced for the design exercise. Ti-refore, a relatively high heat flux of about $0.7 \mathrm{~W} / \mathrm{cF}^{2}$ was desipned for recovery at $900 \mathrm{~d}$, the operational current at a $6-T$ peak field. This hiph-heat flux desion was basac in part on the belief that heat flux through intertuen heat contucijon and conduct ion along conductor cold ends would corteribute to the recovery. Therefore, the nazaet is only conditionaliy stable, and the stinility and the coil disturbunces rust be curefully verified experiental'; and analytically.

First we rodeled the cooling thanel gearetry to ceterine the recovery curreat far several cooling channel heights for the bendirg width, and for several possible conductor turn-to-iurn insulation schetes. For instance, when tine banding width is equal to or greater than $20 \mathrm{rm}$, the recovery current begins to be affected, lext, we found that the proposed corsuctor recovery cursent is not affected even when several nomal adjacent turns exist. Third!y, we found tirat the recover; surrent is reduced by $10 \%$ if cooling channel teight is reduced fron 5 . to $2.1 \mathrm{ra}$, and by $15 \%$ if it is reduced co $1.4 \mathrm{ra}$. Lastiy, we found that if the corcusor is covered by a filotype insularor, e.g. Aupton film, alchough it is as this as $0.002 j$ a $(0.1$ mils), the reccupry curtent was cut in hitf. On the other hand, if the conductor is insulated vith $0.005-0$ varnish file such as forma, tha recovery current is redued by only $5 \%$.

Sirple calculacions on the conductor stability went as follows: The concucto: in each coil pancake will have its $50^{*}$ conductor edazs cooled by liçuid halive. The cooling channel betwean layers is $0.53 \mathrm{~cm}$. $0.95 \mathrm{cr}$. The betted arat rill renove about 0.025 Hatt per ca length of conductas. Heat cransfer through the turn-to-turs itsulation to neighboring cold turns accounts for a minimis of 0.105 $H / c n$, and the heat generation ( $I^{2} R$ ) per car conductor length is $0.135 \mathrm{~g} / \mathrm{cm}$. Thus, the heat conduction along the conducto provides the stabilicy margin if needed. In shott, the tagate is stable againsc certain cransient disturbance energy. Fig. 5 shous the computed ninioum propagating current versus the perturbation energy. It is seen chat at 900 A operating current, a pertutbing energy equal or greater than 9.4 Joule will trigger a nomal zone propazation. This is equivalent to the work done by the electromagnetic iorce on a section of conductor of about 10 cr chat suddenly slips 2 mot a magntic field region of shout $3.5 \mathrm{~T}$. Also show is the experifental data measured using a two-dimensional, 25-cadian. sarple coit and is sirulated heater coupund with the conductor to sirulate the rechanital perturbation. The coil is noninductively wound and the experizent is carried out under a 3.5-T extrrnal field. The conducto:s used are grade $B$ and about 30 aecers long. The reasured cata are generally wuch better than the calculated ones. The experisental data definitely indicate that the nagnet will be stable against a disturbance of about $2 \mathrm{~J}$.

C. Performance Tests and Observed Coil Disrurbances--The magnet was energized at increngncal steps of current. The magnec energy vas dumped at the end of each chatging step. It was Einally charged to full field without any problem.

The principal concern for the U.S. SCHS coil stability was the fricrional heating associated with conductor motion. Two methods were used to detect the cechanical rotion. One involved the use of accelercreters which are rounced on the magnet vessel. The other involyed the use of cany potentioveters connected actoss the magnet reminals. The inductive voltage of each coil could be bucked out by proper adjustent of the center tap of each potentioneter. It was found that the second gethod was very sensitive, and the inforpation obtained proved exceedingly valuablo in deterwining the charging rate. 


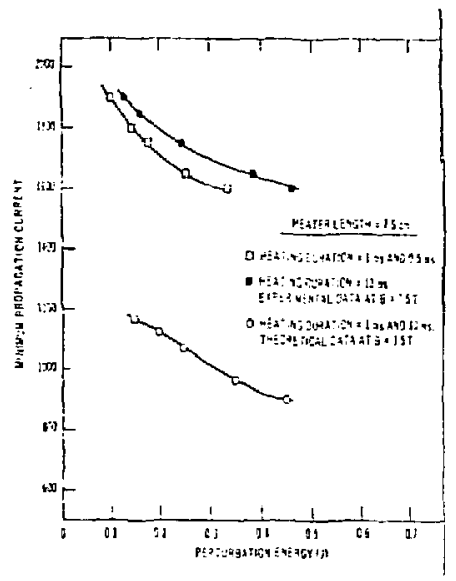

Fi3. j - stabiliey s:aulation test and comparisen $: r i t h$ the cical data
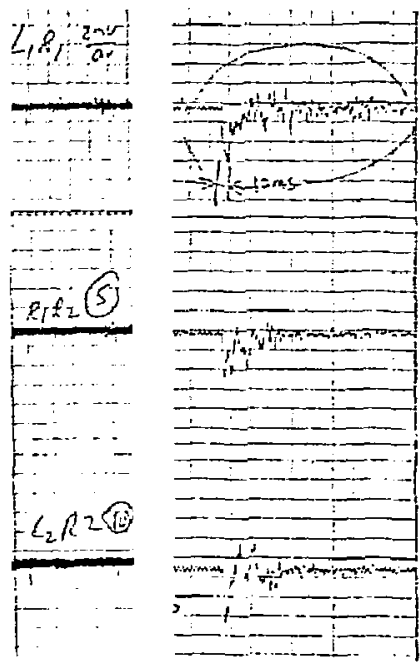

Fij. 6 - li-25s naz̧net zectanica: perturiation azplituce

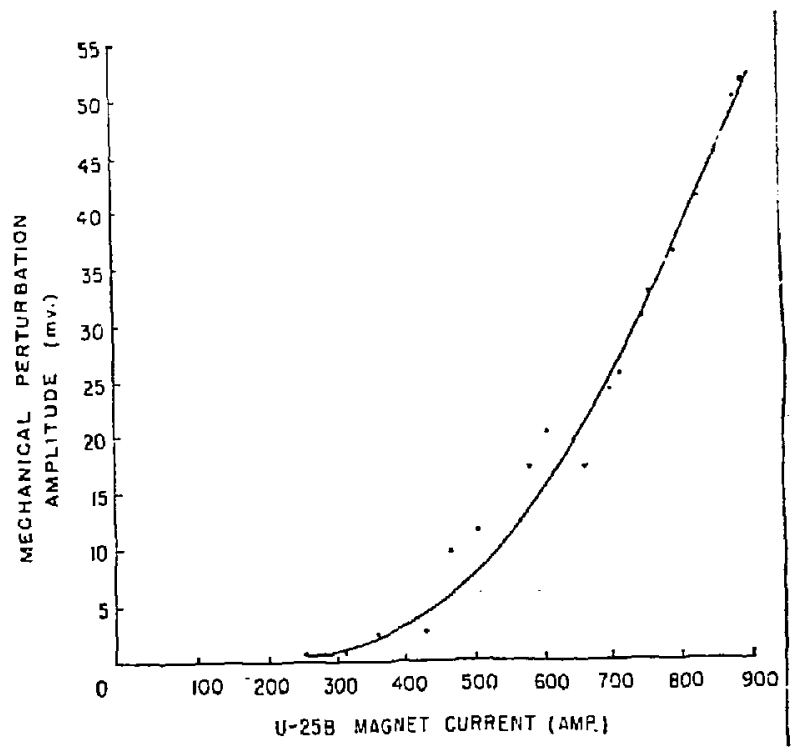

Fiz. 7 - ت̈echanical perturbation amplicude varies as $B^{2}$ 
The typiral frictional notim is thp darpud cacillacions as shou in Eis. 5. It is seen that the desails of a conturtor socion could be very compler in nature. s typical time constant for conductor notion is on the order of $10 \mathrm{~ms}$.

The fercurbation anplitudes increase approximately as $\mathrm{B}^{2}$. This is show in Fiz. 7. In addition to the larger perturbation, one found that mo:e nemerous corductor rotions per increment of pagnet current occurs in the high ijels teye:. Sirce the ferturbation arplitude consists of both the inductive valtage and the resistive volrage, it is not pessibie to derive the disturbance energy from this inforistion.

\section{THE COAL-FISED FLOH SAD EACILITI SUPERCOHDLCTINC DIPOLE MAGHET $/ 4,5 /$}

A. Ynonet Desien Soviet--On nugust 30, 1981, the Argonne Nationa i Labcratory successfully tested a large-aperture superconducting vid magnet for use in tie Cod1-Fired flow facilicy at Tullikoma, Tennessee. The CFFF MHD ragret generates a

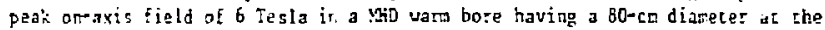
in!e:, a lGC-cn diameter at the outlec, and a 312-cre effective length. The stozed onerey of the raphet is $210 \mathrm{MJ}$. The cold rass $(h-2 \mathrm{~K}$ ) is 131 metric tons and tae angeremcurns $13 . i \times 10^{6}$.

The mupet consists of fourteen concentric layers with a shorier coil (cail layer vo. 1) close to the bore cube. The coil shape is a circular sacdile uhich will support the hoop stress of the coil end irself. The significant vagnet characteristics are listed in Table II. Th wagnet geonetry is shoun in $\bar{r}$ iz. 8 . Coil layer strycture is similat to that of U.S. SCt5 except that the stainless steel banding is replaced by pultzuded fiberglass banding.

As show in Fig. 9, the conductor is a soldered assenbly of a superconducting eable of $M b-4 B^{*} \mathrm{Ti}$ composite wires that fits into the longitudinal groove of the o: $4 \mathrm{C}$ copper stabilizer. Three grades of conductors are used: Grade h vith a $4.2 \mathrm{~K}$ short sapple ericical current of $4400 \mathrm{~A}$ at $7.5 \mathrm{I}$; Grade $\mathrm{B}, 4400 \mathrm{~A}$ at $6.5 \mathrm{~T}$; and Grade $c, 4600 \mathrm{~A}$ ac $4.5 \mathrm{~T}$. The operacing poinc is $3520 \mathrm{~A}$ at $4.2 \mathrm{~K}$ with a field argin of 0.5 I for each grade of conductors. All conductors have a height of 3.1 en with conductor thickness varyirg according to the field grades. The surface of superconducting cable is recessed belou the stabilizer surface by $0.75 \mathrm{\pi m}$, thus fomirg a longicudinal cooling charcel for the cable. Also show in Fig. 9 is the turn-zo-tum insulation which is a pulcruded fiberglass strip with a keystone czoss section. It is punched in a fistbone-like pattern for providing about 30 cooling on both conductor broad faces.

Eacn layer of coil consists of a pair of saddle coils. Pultruded-fiberglass banding, $18.5=$ wide $X 7$ man thick, is banded over the coil layer leaving a $18.5 \mathrm{~cm}$ spacsing between two bands in the straight conductor region and $6.2 \mathrm{ma}$ in the coil end region.

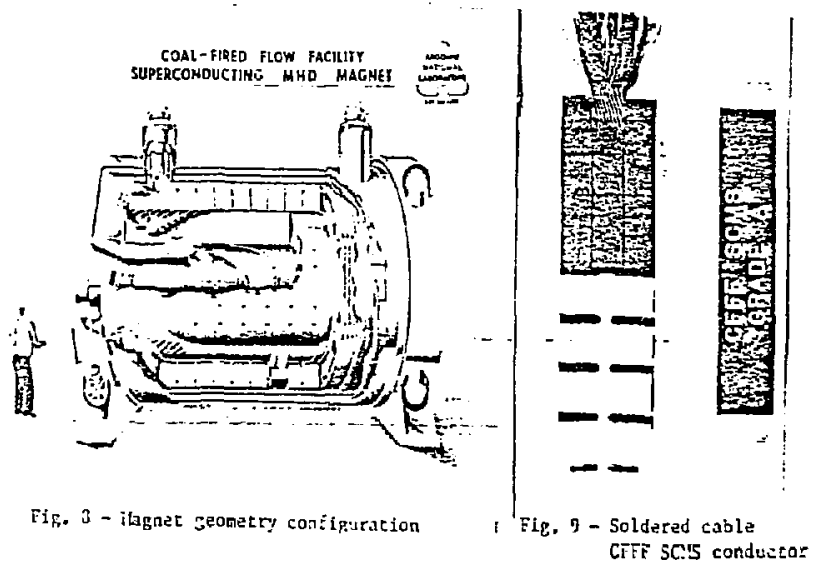




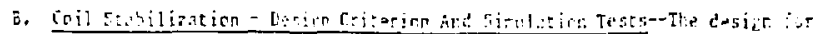

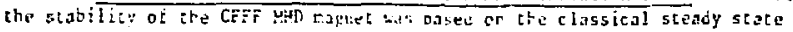
stability criterion, because the condstidral stahitity rccuirec a good guess at the size of possible disturbance thich is cifficult to estinate. The copper cross

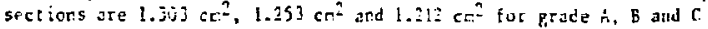
condectors, respectivel:; The current darsities er, the cop?er are $2800 \mathrm{~A} / \mathrm{Co}^{\text {? }}$, ? $600 \mathrm{~N} / \mathrm{Cn}^{2}$, nd 3000 aico corductors. Boti the face-coolire and cune-cooline are enployed. The I'? per c-

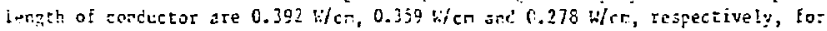

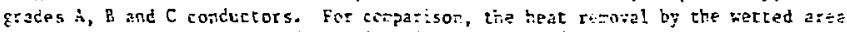

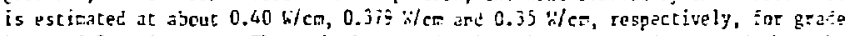
$A, b$ and $C$ conduetors. Thus, the heat concuction along the corductor arc itrough the rurn-to-cura insulation till provide attitiona: nargins for stability.

To obtait the kajt-tzunsfer data and the eifect of hiliun vapor within the chanel on the heat cranster, sarpies of copper chrcuctor having coniligurations

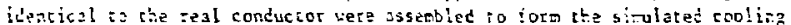

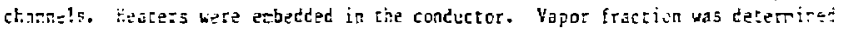
by roaguige the change in the capacicance of the channel $/ 6 /$. The measurec steady state heat transfer characteristics shown in Fig. 10 indicate that the maximu

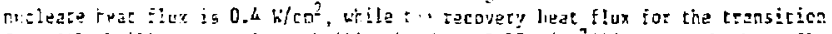

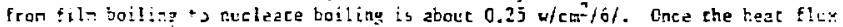
excescs $0.4 \mathrm{l} / \mathrm{cr}-$, the tergerature will rise sudcenly iran $4.4 \mathrm{x}$ to abouk $11.2 \mathrm{O}$

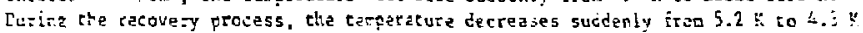
then the rucleate boiling regite is attaired,

Using tine reasured steady state heat cransfer curve, one could congute the cold-end recovery certent and the absolute stable current. This is show in Fig. 10. It is seen that, For the CFF SCH'S grade $h$ Conductor, the cold end recover: custent is about $5700 \mathrm{~A}$ and the absolute stable current is $4800 \mathrm{~A}$. Also 5 hown $\mathrm{i}:-$ $\Xi: g$. 10 ate the heat generation curves $\cos 3750 \mathrm{~A}, 5484 \mathrm{~A}$ and $5750 \mathrm{~A}$.

Figure $1 \mathrm{i}$ shors the results of short sample tests far the three grades of conductors. Also shown in this $\mathrm{Fi}_{\text {gute }}$ are the confuctor specitications, the operating points and the neasured dasu fer both the minimu propagating current and the recovery cuzrerts for each grade of concuctor. It is seen that sutficiert aa $\because$ ins for conductor short sapple capabilicy and the conducter stability exist for tire conductors ecployed.

To test Eurther the conductor stability, a $24-\mathrm{cm}$ long, grade A conductor wes heated over the 7.5-cm riddle region under an external magnetic field of $7.5 \mathrm{I}$ at $3700 \mathrm{~A}$. The conductor remained stable even after it was heated to a temperature of $37 \mathrm{~K}$, zbsorbing a total power dissiparion of gore than 173 Warts. However, then the conductor was heated to about $54 \mathrm{~K}$, themal tumanay occurred.

The effects of soldering voids on the recovery curtent of the superconducto: werp investigated. Pecovery current vs. void length at different external fields is show in Fig. I2. From thase data, it is elear that in order for the CFF SCYS grade A concuctor to recover at $3675 \mathrm{~A}$, the void length should be shorter than 3.8 ch. Hote that the grade A conductor with $25.4-\mathrm{car}$ void length could only recover at a currenc of I600 A:!

C. Narnet Performance Tests and observed Coil Disturbances--The prircipal concerns the very first time the latge dipole cagnet was enarized were the fechanical pertuzations fron the canductor wotion, the possible failure of the structural components, and the possible ground fault and integrity of the energization and nagnet prorection systea. Three nerhods vere used ro detect cechanical rotion in general and conductor gotion ir parcicusar the first one involved the use of unbalanced volcages across the various parts of the superconducting coils. The second involved the use of acceleroneters with probes rmanted on the outer faces of the end flanges of the heliur vessel. The third aployed the acoustic exission probes. It turns out that the first method uas very 


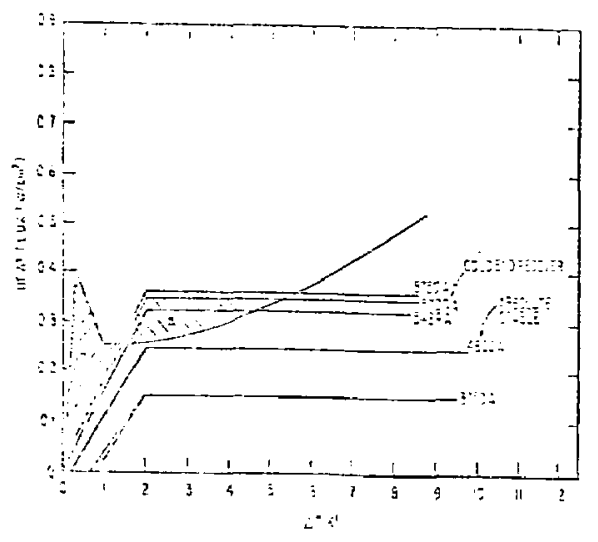

Fij. IO - Grejhical andisis of conductor

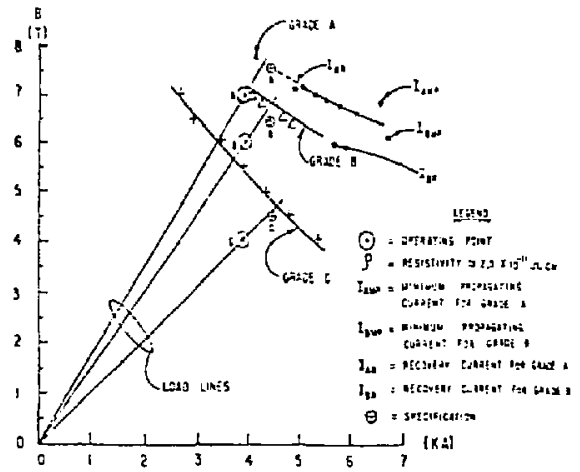

Fig. 11 - CFF conductor scabifity liait and short-sample characteristics

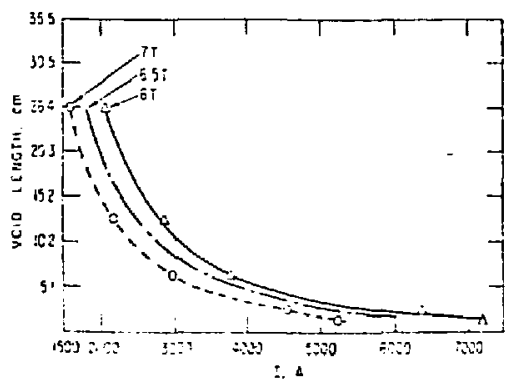

Fis. 12 - The vid eitece on the recovery current 


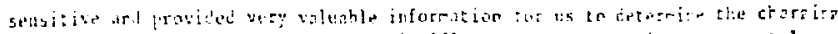
ratc. Tha cosults indicated that no sifrificant cosfecter rotion cecurs at lowet

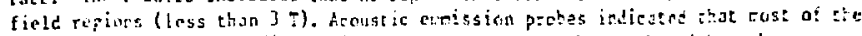
rotion Decurrul at hik. field coil pats. Ca the cther bacd, the tigher the

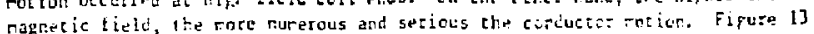
stows the detailed cine resoluticn of the unbalanced voltozes. It as evicert tits

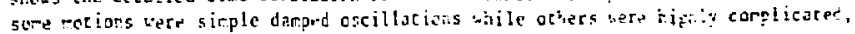
uncer-iarped ascillations.

\section{$\underline{\text { TAILË }: \bar{Y}}$}

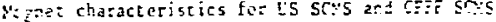

tS Si:'s

$4 \tau$

$5 \tau$

3.2 T

2.550

0.6 a dis.

0.6 a $2 \vdots 3$.

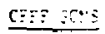

I. un related fartiters

prak

Ef =erive rasret is length

liars bore:

inlet

ouclet

II. Yasaet characeptistics

Hinclas? $i$. ट.

Hinding o.d.

hicring axizl lergth

ro. of layers

Stored arergy

Incuctance

artheze-turts

Arpert-aeters

Operarional current

Concuctor peak field

Conductor cutrent density

Coolire

tieat flux

Corduc tor weight

sognet weighe

\begin{tabular}{|c|c|}
\hline $3 s=m$ & lic es \\
\hline $\begin{array}{l}70.4 \text { сп } \\
3.75 \text { n }\end{array}$ & $\begin{array}{l}225.7 \mathrm{cs} \\
4 . \mathrm{ES}=\end{array}$ \\
\hline 23 & 14 \\
\hline $34.2 \mathrm{WJ}$ & $210: 3$ \\
\hline 84.511 & $32 \leqslant$ \\
\hline $6.3 \times 10^{5}$ & $33.7 \times 10^{6}$ \\
\hline $52 \times 10^{6}$ & $145 \div 10.5$ \\
\hline $892 A$ & $3672 \mathrm{~A}$ \\
\hline $6 T$ & $7 \mathrm{I}$ \\
\hline $4400 \mathrm{~A} / \mathrm{CH}$ & $2500 \leq i==^{2}$ \\
\hline Pool toiling & Pool boiling \\
\hline $0.7 \mathrm{~b} / \mathrm{cm}$ & $\begin{array}{l}0.15 \mathrm{k} / \mathrm{cm}^{\circ} \\
48.000 \mathrm{~kg}\end{array}$ \\
\hline $37,000 \mathrm{ks}$ & $177,00 \mathrm{sg}$ \\
\hline
\end{tabular}

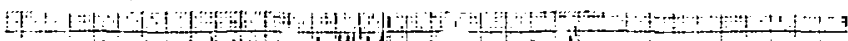

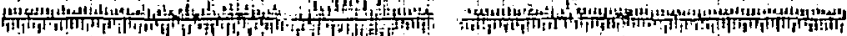

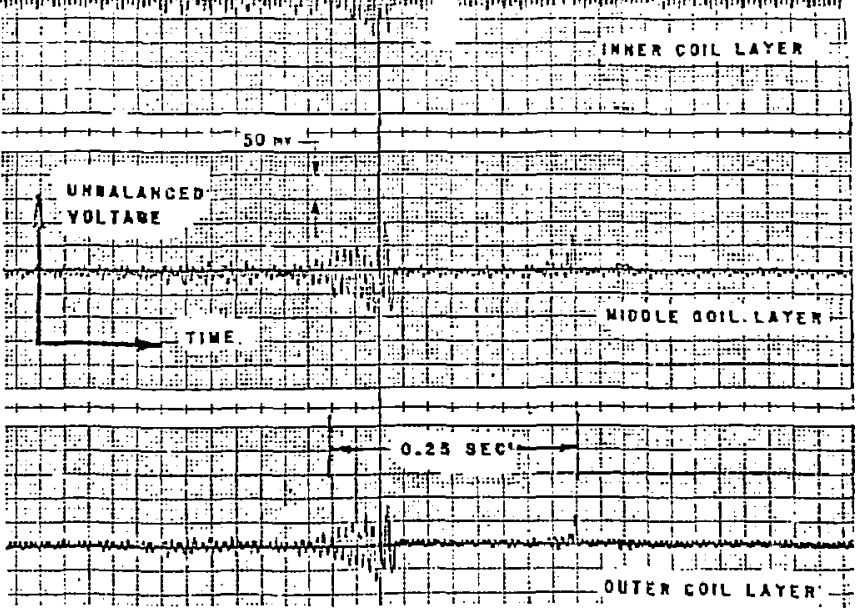

Fig. 13 - Detail time cesulusion of corductur nut ion jot CFF sc:5 


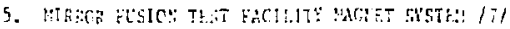

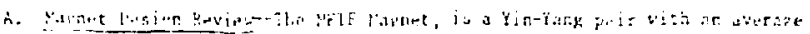

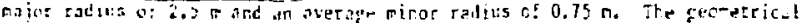

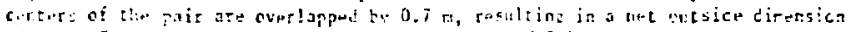

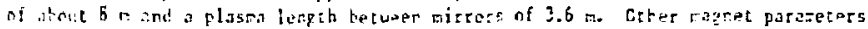

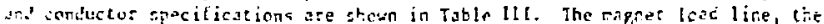

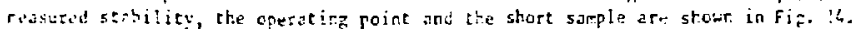

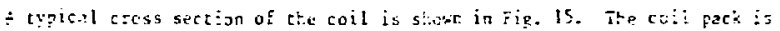

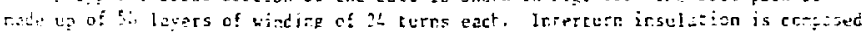

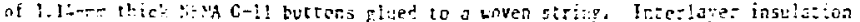

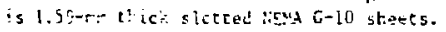

\section{TALLE III}

:-TF ragnet yararaters and conductor apociticationa

I. Yagma paraneters

\begin{tabular}{|c|c|}
\hline Colis & Eool bolling \\
\hline co-cuctor peax Ejeld & $7.55 \mathrm{I}$ \\
\hline Firir at rizror & $4.2 T$ \\
\hline ̈ir!d at cencer & $2.0 \mathrm{~T}$ \\
\hline Vitroi-totiveor lengin & 3.t. $\square$ \\
\hline Chare: ine cureser & $5773 \mathrm{~h}$ \\
\hline io of curns per coil & 1392 \\
\hline Toti: stored energy & $405 \mathrm{NJ}$ \\
\hline Creciesor cuirent denait; & $3720 \mathrm{~m} / \mathrm{cm}^{2}$ \\
\hline Average currert temsity & $2525 \mathrm{~A} / \mathrm{cr}^{2}$ \\
\hline Conructor lenget get rcil & $20 \mathrm{kn}$ \\
\hline Total cold na:s weipht & $34 !, 000 \mathrm{~kg}$ \\
\hline
\end{tabular}

17. Concluceor specification

A. Supercanciucting coze Skort sample core size

C1,ibii

Cepper resistance zatio

Fo. of filament

Fil a went ciameter

Filament twigt pitch

$10 \mathrm{ith}$ at $7.5 \mathrm{I}$ and $4.2:$

6.5 ก. $\div 6.5=$

$1.7: 1$

$150: 1$

480

$0.20 \mathrm{~m}$

180 ताय

B. Perforaced sheach copfer stabilizer Resistivity ac $7.58 \mathrm{~T} 44.5 \mathrm{~K}$ Stabilizer resistivicy racio

$4.6 \times 10^{-6} 0 \mathrm{hm}-\mathrm{em}$ $220: 1$

C. Overall corductor assembly Copper to superconductor ratio overall size

$6.7: 1$

Soft solder

$12.4 \mathrm{~cm} \ddot{\mathrm{A}} 12.4 \mathrm{~cm}$

50-50 Pb -50

D. Conductar srabilicy Helium uetted area Extectial open channel

Internal perforated channel Average recovery heac $f$ lux Yeasured stability limic I" 2 per es length

Total $8.17 \mathrm{cn}^{2} / \mathrm{cm}$

$2.54 \mathrm{cr}^{2} / \mathrm{cs}$

$5.63 \mathrm{~cm}^{2} / \mathrm{cm}$

$0.19 \mathrm{w} / \mathrm{Ca}^{2}$

1.55 wer

$1.28 \mathrm{wer}$ 


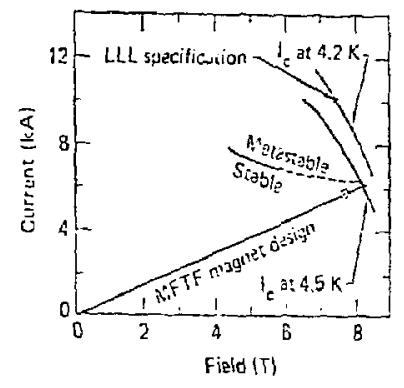

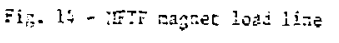

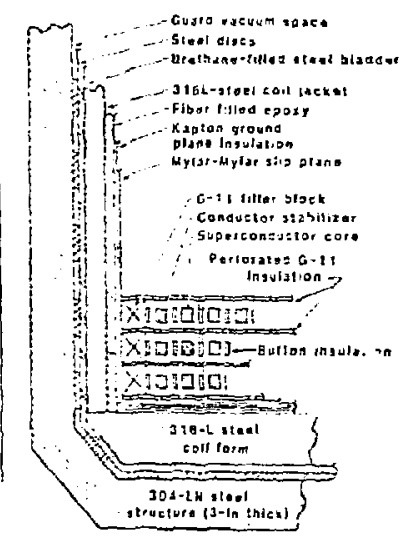

Fi;. 15 - Coil assably coos sec:ion

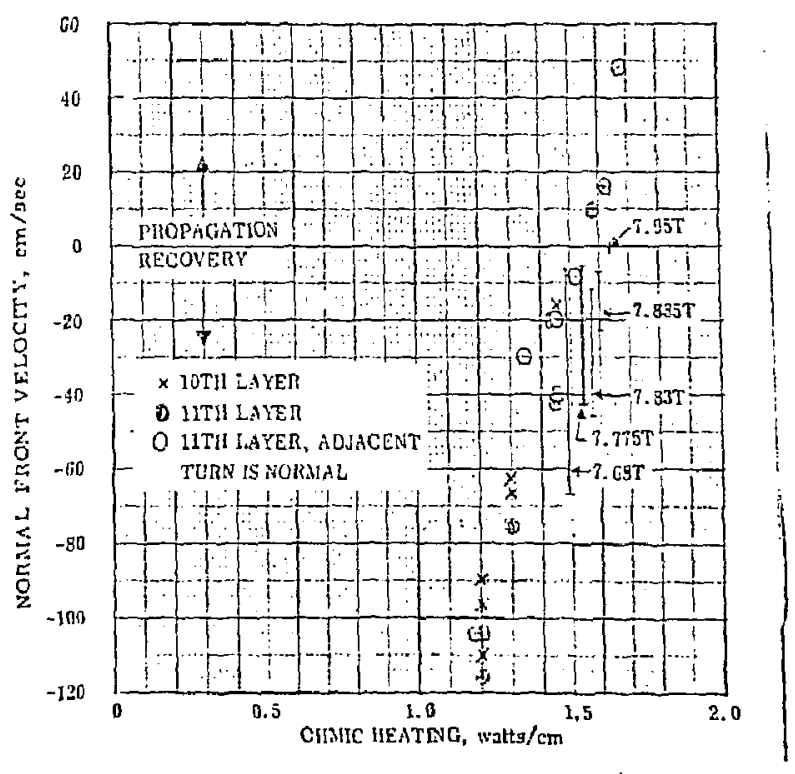

Fig. 15 - IFIF adonet conductor crostabilicy analyis data conparison with 1-a-bore test dati 


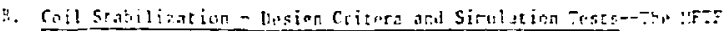

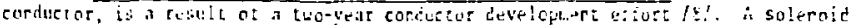
coil, 10i-ce insida and 167-cr nutsite diareter with axisl coil leryth of $25.5 \mathrm{cre}$, was constructed to test the scobility perforsance of the ifif corchictor. The insulation systep between the pancakes and the curss is itanticai to that of the MTF cnil structure. Howal zones cere created by pulsirz teaters nctached to the ccriductor. This scuey bas established the stability linit tine onset of the pesitive nowsl front propagation) for the conductor at $1.55 \mathrm{~g} / \mathrm{col}$ let.th of the

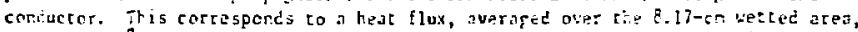
of $0.19 \% / \mathrm{c}$. This experichental observacion can be explaires by a:eragis? heat fluxes oi $0.5 \mathrm{w} / \mathrm{cr}^{2}$ ard $0.1 \% / \mathrm{cs}^{2}$ over the gen external anc the custricted internal cooling surfaces, respectively. The ragnet lose lire is stosin is Fip. 14.

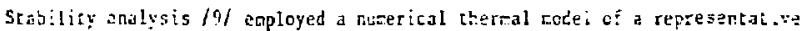
lergth of the isto stabilized conciuctor. Tre cistubance corcitior was sirulated by imposirs a terperature of $30 \mathrm{~K}$ on a $40-\mathrm{ce}$ ection of the concuetcs. The disturbarce conditior correspunds to a cisturbance energy inpte o: 2.6E5 $\mathrm{J} / \mathrm{co}^{2}$, far excaedira the roiling heat extraction capacicy of the sirgle corductor local beliva invarsor:- Tre analysis uses the conductor caoling characte:istics derived frci tha ahove experimental data of the stability-cail tests. Fig. I6 stows the resul: o: :he andysis compared with the ceasured tara fren the siajility coit. frce this, one coneledej that at a 7.95-t peak tiele, the eagnet wi!l cuench in Iesporse to a diseirbance of $2.035 \mathrm{~J} / \mathrm{er}^{3}$; that $\mathrm{i}$ s, a 40-ca sectior of conéuctor initislly romal it a terpe sture of $20 \mathrm{k}$, will trigger the clench oz the :ETf

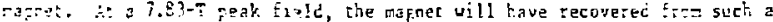

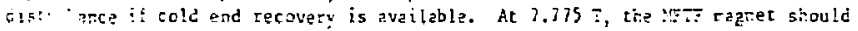
tei pren buth erds of tie noral zone are hor.

\section{REFERE:ICES}

1. J. El'zeit: The supercondueting ragnet syster for the 12-foot tubble chaiber. Aili/ite? 6813 (1969).

2. J. PUPCELL, \#. DESPORTES, and D. JQNES: Superconducting ragnet for the 15-5oor lial bubb!e chamber. AiL/HEP 7215 (1973).

3. 5. T. HitG, et al.: The U.S. SCYS dipole magnet for the bypass loop of the L-25 NML facility. Sixth Int. Conf. on Magret Technology, Eratislava, Crechoslovakia, (1977) pp. 157-152.

4. 5. T. Witce et al.: tinal design of a superconductisz rid ragnet fo: the coal-fired flow facility at the University of Tennessee Space irstitcte. Advances in Cryogenic Engineerirg, Vol. 25 (1950) pp. 15-29.

5. 5. T. hili:G, et al.. Fabrication experiences and performance tests of the coal-fired flow facility supercondusting dipole nagret. Subritted to Cryozenies (โดฐi).

6. C. J. CHAH, S. I. HALG, J. H. D.WSÖ: Vapot locking and heat transfer of mulcipie layers. IEEE Iransactions on Magneties, MAC-17 (1991) pp. 1097-1090.

7. C. D. Eet:tirs, et al.: Mirror Fusion Test Facility Yagnet Systen - Einal Design Rzport. UC?L-52955, (1980).

8. D. li, CORHiLH, et al.: METF test coil constetetion and perforeance. IEEE Transact ions on Yagnetics, MaG-15 (1979) p. 530.

9. R. F. O't:ElL and D. H. RIENER: Themodynamic analysis of the cagnet systed for :irtor Fusion Test Focility. General Dynadies Report tio. CASD-LLL $78-002$ (1075) Chapter 3. 


\section{DMCLI] WH:}

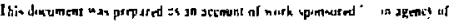

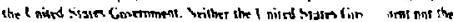

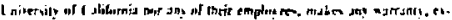

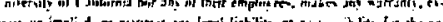

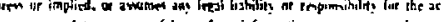

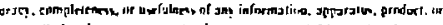

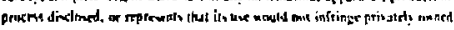

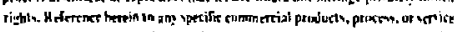

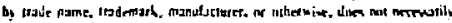

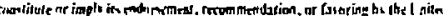

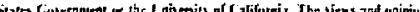

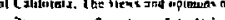

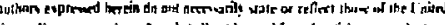

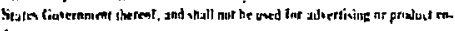
directarat purporen 